\title{
Analisa Zat Gizi, Kadar Asam Lemak, serta Komponen Asam Amino Nugget Daging Kelinci New Zealand White (Oryctolagus cuniculus)
}

\author{
Rahma Micho Widyanto ${ }^{1}$, Titis Sari Kusuma ${ }^{2}$, Ardhila Lovi Hasinofa ${ }^{3}$, Adelia Paradya \\ Zetta $^{4}$, Frisa Inda Vega Br Silalahi ${ }^{5}$, Rakhmawati Widya Safitri ${ }^{6}$ \\ 1,2,3,4,5,6 Jurusan Gizi, Fakultas Kedokteran, Universitas Brawijaya, Jl. Veteran, Malang, 65145 \\ Penulis untuk Korespondensi/E-mail: $\underline{\text { micho@ub.c.id }}$
}

\begin{abstract}
Abstrak - Nugget merupakan salah satu jenis produk olahan beku siap saji yang sering dijumpai di tengah-tengah masyarakat. Kelinci New Zealand White (Oryctolagus cuniculus) adalah jenis kelinci yang dikembangkan untuk tujuan pedaging. Pembuatan nugget daging kelinci dalam rangka untuk meningkatkan upaya diversifikasi produk olahan daging. Bahan yang digunakan dalam penelitian ini adalah daging kelinci yang diolah menjadi nugget. Penelitian ini bertujuan untuk menganalisis kadar proksimat, kadar asam lemak dan asam amino pada nugget daging kelinci jenis ras New Zealand White (Oryctolagus cuniculus). Rancangan penelitian menggunakan 3 kali ulangan untuk setiap sampel pengujian. Hasil pengujian menunjukkan nilai proksimat daging kelinci adalah protein sebesar $10.71 \mathrm{~g}$ per $100 \mathrm{~g}$ sampel, kandungan air sebesar $54,66 \%$, kadar abu sebesar $1 \%$, karbohidrat sebesar $30,29 \%$. Kadar asam lemak jenuh per $100 \mathrm{~g}$ sampel adalah $1.16 \mathrm{mg}$, sedangkan kandungan asam lemak tidak jenuh per $100 \mathrm{~g}$ sampel adalah $1.17 \mathrm{mg}$. Untuk hasil kandungan asam amino esensial per $100 \mathrm{~g}$ sampel adalah : Histidin : 0.42g, Arginin : 0.75g, Treonin : 0.54g, Valin : 0.60g, Isoleusin :0.54g, Leusin :0.94g, Penilalanin : 0.59g, dan Lisin : 1.01g. Sedangkan kandungan asam amino non esensial per $100 \mathrm{~g}$ sampel adalah : Asam aspartat: 1.18g, Asam glutamat: 2.31g, Serin: 0.58g, Glisin : 0.69g, Alanin : 0.90g, dan Prolin : 11.63g. Dengan kandungan gizi yang cukup baik, daging kelinci bisa menjadi alternatif bahan nugget untuk pemenuhan kebutuhan gizi keseharian
\end{abstract}

Kata kunci - nugget kelinci, proksimat, asam lemak, asam amino

Abstract - Nugget is one type of processed frozen ready-to-eat products that are often found in the midst of society. The New Zealand White Rabbit (Oryctolagus cuniculus) is a type of rabbit developed for the purpose of broilers. Making rabbit meat nuggets in order to increase the diversification efforts of processed meat products. The material used in this research is rabbit meat that is processed into nuggets. The aim of this research is to analyze proximate, fatty acid and amino acid content on rabbit nugget of New Zealand White (Oryctolagus cuniculus). The study design used 3 replicates for each test sample. The result of the test shows that the proximate value of rabbit meat is protein of $10.71 \mathrm{~g}$ per $100 \mathrm{~g}$ sample, the water content is $54,66 \%$, the ash content is $1 \%$, the carbohydrate is $30,29 \%$. The saturated fatty acid level per $100 \mathrm{~g}$ sample is $1.16 \mathrm{mg}$, while the content of unsaturated fatty acids per $100 \mathrm{~g}$ sample is $1.17 \mathrm{mg}$. For the results of the essential amino acid content per $100 \mathrm{~g}$ of sample are: Histidin: $0.42 \mathrm{~g}$, Arginine: 0.75g, Treonin: 0.54g, Valin: 0.60g, Isoleucine: 0.54g, Leusin: 0.94g, Penilalanin: $0.59 \mathrm{~g}$, and Lisin: $1.01 \mathrm{~g}$. While the content of non essential amino acids per 100g of sample are: Aspartic acid: 1.18g, Glutamic acid: $2.31 \mathrm{~g}$, Serine: 0.58g, Glycine: 0.69g, Alanin: 0.90g, and Prolin: 11.63g. With a fairly good nutritional content, rabbit meat can be an alternative ingredient nugget to meet the daily nutritional needs

Keywords - rabbit nugget, proximate, fatty acid, amino acid 


\section{PENDAHULUAN}

$\mathrm{K}$ onsumsi daging kelinci di Indonesia masih tergolong rendah yang mencapai $0,27 / \mathrm{kg} / \mathrm{kapita} / \mathrm{tahun}$. Jika dibandingkan dengan sumber protein hewani lain seperti daging sapi yang konsumsinya mencapai $2,08 \mathrm{~kg} / \mathrm{kapita} / \mathrm{tahun}$ dan daging ayam yang konsumsinya sebesar 4,5/kg/kapita/tahun tentunya konsumsi daging kelinci masih rendah [1] [2].

Daging kelinci sendiri memiliki keunggulan dalam beberapa kandungan zat gizi. Kandungan zat gizi dalam 100 gram daging kelinci mengandung kadar air $67,9 \mathrm{~g}$, protein 20,8 g, lemak 10,2 g, dan kadar abu $1 \mathrm{~g}$.

Kelinci jenis New Zealand White merupakan kelinci penghasil daging karena berbadan gempal dan memiliki daging yang padat. Kelinci jenis New Zealand White ini dapat dikawinkan ketika mencapai usia 18-19 minggu untuk pejantannya. Kelinci jenis New Zealand White memiliki masa bunting selama 29,55 \pm 0,95 hari dan dalam peranakan dalam sekali kelahiran adalah 7,05 $\pm 0,95$ ekor [3].

Produk olahan daging kelinci sudah banyak digunakan menjadi bakso, abon, sosis, dengdeng dan nugget. Namun, sebagian masyarakat Indonesia belum terbiasa mengonsumsi daging kelinci, karena kelinci dianggap sebagai hewan kesayangan. Selain itu, kehalalannya masih diragukan bagi masyarakat muslim. Tanggal 17 Jumadil Awal $1403 \mathrm{H}$ yang bertepatan pada 12 Maret 1983, MUI menetapkan fatwa dalam sidang yang dilakukan di Jakarta bahwa daging kelinci hukumnya halal [4].

Nugget sebagai salah satu produk olahan daging merupakan daging yang digiling, diberi penambahan bumbu, dicetak, kemudian dilumuri tepung roti pada permukaannya lalu digoreng [5]. Nugget menjadi produk yang diminati masyarakat dikarenakan mudah didapat, tidak memerlukan banyak waktu untuk dimasak, dan pengaruh lingkungan yang juga menyukai makanan cepat saji.

Mempertimbangkan keunggulan yang dimiliki produk makanan dalam bentuk nugget dan juga kandungan zat gizi yang baik pada daging kelinci maka terbentuklah sebuah inovasi yaitu nugget kelinci. Kandungan zat gizi yang tinggi pada daging kelinci yang dikombinasikan dengan produk nugget yang digemari masyarakat akan menjadi daya tarik tersendiri dari produk ini. Dikarenakan berbagai manfaat dari nugget kelinci yang telah dijelaskan di atas maka peniliti tertarik untuk meneliti kandungan nilai gizi (protein, asam lemak dan asam amino).

Tujuan dari penelitian ini adalah untuk menganalisis kadar proksimat, asam lemak dan asam amino pada nugget daging kelinci New Zealand White (Oryctolagus cuniculus). Diharapkan penelitian ini dapat menjadi informasi dasar mengenai kandungan nilai gizi dari nugget daging kelinci sehingga mampu meningkatkan pemanfaatan potensi daging kelinci sebagai produk olahan daging

\section{METODE PENELITIAN}

Pembuatan nugget dilakukan di Laboratorium Penyelenggaran Makanan, Fakultas Kedoteran, Universitas Brawijaya. Sedangkan untuk pengujian proksimat dilakukan di Laboratorium Pengujian Mutu dan Keamanan Pangan, Fakultas Teknologi Pertanian, Universitas Brawijaya; uji kadar asam lemak dilakukan di Laboratorium Saraswanti Indo Genetech, Bogor, dan pengujian komponen asam amino di Mbrio Food Laboratory, Bogor. Penelitian ini dilaksanakan selama Juni 2017 - hingga September 2017.

Bahan baku yang digunakan adalah daging kelinci jenis New Zealand White dengan jenis kelamin jantan, usia 3-4 bulan, berat hidup 2.2 $3 \mathrm{~kg}$ yang didapat dari Komunitas Kelinci Kediri (K3). Bahan pengikat dan bahan tambahan yang digunakan adalah tepung maizena, tepung roti, susu cair tanpa lemak, tepung terigu, telur ayam, bawang putih, merica bubuk, garam dan gula pasir.

\section{Prosedur penelitian}

Penentuan formulasi nugget berdasarkan resep yang sudah diterapkan pada produk nugget kelinci K3. Perbandingan bahan formula nugget adalah sebagai berikut : 
Tabel 1. Komposisi bahan per $100 \mathrm{~g}$ nugget kelinci

\begin{tabular}{lc}
\hline \multicolumn{1}{c}{ Jenis bahan } & $\begin{array}{c}\text { Berat } \\
(\mathrm{g})\end{array}$ \\
\hline Daging kelinci & 30 \\
Telur & 29 \\
Tepung roti & 18 \\
Tepung maizena & 10 \\
Susu cair tanpa lemak & 6 \\
Tepung Terigu & 4 \\
Bumbu (bawang putih, & \\
merica bubuk, garam, gula & \\
pasir) & 3 \\
\hline Total & 100 \\
\hline
\end{tabular}

Disain penelitian dapat dilihat pada Gambar 1 berikut :

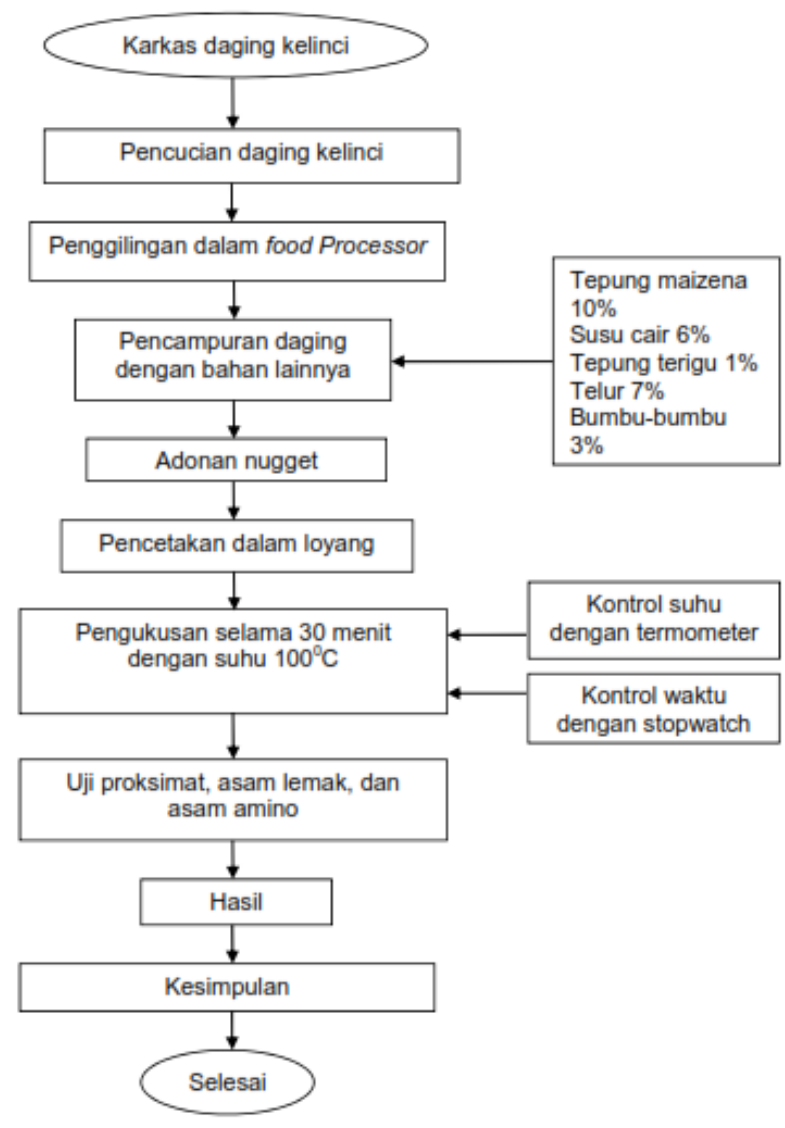

Gambar 1. Bagan alur prosedur penelitian

\section{Prosedur pengujian}

Penelitian ini diawali dengan pembuatan nugget sesuai dengan resep dari produk nugget kelinci K3, kemudian dilanjutkan dengan analisis kandungan kimia sampel nugget yang meliputi: protein, kadar air, kadar abu, lemak total, dan karbohidrat. selanjutnya dilakukan pengujian kandungan asam lemak serta komposisi asam amino.

\begin{abstract}
Analisis Data
Penelitian ini dilakukan pengulangan sebanyak 3 kali dengan sampel berupa nugget yang diformulasikan sesuai dengan resep produk dari K3 [6] [7].
\end{abstract}

\section{HASIL DAN PEMBAHASAN}

\section{Proksimat (protein)}

Hasil analisis kadar protein nugget kelinci New Zealand White sampel 1 mengandung protein sebesar 10,16\%, sampel 2 mengandung 10,84 $\%$, dan sampel 3 mengandung $11,12 \%$. Ratarata hasil analisis protein adalah $10,71 \%$ (Tabel 2)

Tabel 2 Kandungan Protein dalam 100 g Nugget Kelinci New Zealand White

\begin{tabular}{ccccc}
\hline \multirow{3}{*}{ Parameter } & \multicolumn{3}{c}{ Sampel } & $\begin{array}{c}\text { Rata- } \\
\text { Rata }\end{array}$ \\
\cline { 2 - 5 } & 1 & 2 & 3 & 10,71 \\
\hline $\begin{array}{c}\text { Protein } \\
(\%)\end{array}$ & 10,16 & 10,84 & 11,12 & 10 \\
\hline
\end{tabular}

Kadar protein dari nugget kelinci New Zealand White lebih rendah apabila dibandingkan dengan syarat mutu kandungan protein nugget ayam, yaitu minimal $12 \%$ [8]. Hal ini disebabkan karena kandungan daging kelinci pada sampel nugget hanya sebesar $30 \%$ dari total bahan. Dengan meningkatkan kandungan daging kelinci dapat menaikkan kadar protein pada nugget, hal ini terbukti pada nugget kelinci dengan kandungan daging kelinci lebih dari 50\% mengandung protein sebesar 17\% [9].

Pada bahan pengisi nugget, protein yang terkandung sangat sedikit, yaitu tepung maizena dan tapioka masing-masing hanya $0,3 \%$ dan $0,5 \%$ [9], sehingga tidak mempengaruhi dalam peningkatan protein produk.

\section{Proksimat (lemak total)}

Hasil analisis kadar lemak nugget kelinci New Zealand White sampel 1 mengandung lemak sebesar 3,13\%, sampel 2 mengandung 3,55\%, dan sampel 3 mengandung 3,34\%. Rata-rata hasil analisis lemak adalah 3,34\% (Tabel 3) 
Tabel 3 Kandungan Lemak dalam 100 g Nugget Kelinci New Zealand White

\begin{tabular}{ccccc}
\hline \multirow{2}{*}{ Parameter } & \multicolumn{3}{c}{ Sampel } & $\begin{array}{c}\text { Rata- } \\
\text { Rata }\end{array}$ \\
\cline { 2 - 4 } & 1 & 2 & 3 & 3,34 \\
\hline $\begin{array}{c}\text { Lemak } \\
(\%)\end{array}$ & 3,13 & 3,55 & 3,34 & \\
\hline
\end{tabular}

Kadar lemak dari nugget kelinci New Zealand White sudah sesuai dengan dengan syarat mutu kandungan lemak nugget ayam menurut SNI Nugget Ayam 01-6683-2002 dengan syarat maksimal $20 \%$ berat basah [8]. Kadar lemak pada nugget kelinci New Zealand White termasuk rendah $(3.34 \%)$ jika dibandingkan dengan nugget ayam komersial yang memiliki kandungan lemak berkisar antara 12-15\%.

Kandungan total lemak pada daging kelinci adalah sebesar $10.2 \%$ sedangkan pada nugget daging kelinci mengalami penurunan, yaitu $3.34 \%$. Proses pengukusan pada nugget kelinci menyebabkan lemak akan meleleh sehingga kadar lemak akan berkurang [11] [12]. Selain itu, kerusakan lemak juga diakibatkan oleh perlakuan suhu dan waktu pengolahan. Pengukusan nugget dilakukan pada suhu $100^{\circ} \mathrm{C}$ selama 30 menit, sehingga dapat mempengaruhi kadar lemak pada nugget [13].

\section{Proksimat (kandungan air)}

Hasil analisis kadar air nugget kelinci New Zealand White sampel 1 mengandung air sebesar 54,24\%, sampel 2 mengandung $52,56 \%$, dan sampel 3 mengandung 57,19\%. Rata-rata hasil analisis air adalah $54,66 \%$ (Tabel 4)

Tabel 4 Kandungan Air dalam 100 g Nugget Kelinci New Zealand White

\begin{tabular}{ccccc}
\hline \multirow{3}{*}{ Parameter } & \multicolumn{3}{c}{ Sampel } & Rata- \\
\cline { 2 - 5 } & 1 & 2 & 3 & Rata \\
\hline Air (\%) & 54,24 & 52,56 & 57,19 & 54,66 \\
\hline
\end{tabular}

Kadar air dari nugget kelinci New Zealand White sudah sesuai dengan syarat mutu kandungan lemak nugget ayam menurut SNI Nugget Ayam 01-6683-2002 dengan syarat maksimal $60 \%$ berat basah [8].

Kadar air nugget kelinci New Zealand White dipengaruhi oleh penggunaan tepung maizena sebagai bahan campuran nugget. Tepung maizena mampu mempertahankan air pada adonan yang dikukus hingga suhu $70^{\circ} \mathrm{C}$ dan menyebabkan adonnan menjadi gel. Sifat tepung maizena juga mampu menyerap air beberapa kali lipat dari berat semula yang menyebabkan volumenya meningkat [14]. Tepung maizena mengandung amilosa tinggi, sehingga kandungan pati pada maizena akan bersifat kering dan sedikit mengandung air. Pati pada maizena akan menyerap kandungan air pada daging kelinci sehingga kandungan air pada nugget akan menurun [12] [15].

Selain itu kandungan protein daging mempengaruhi kadar air pada nugget. Semakin tinggi kandungan protein daging akan meningkatkan kemampuan menahan air di daging sehingga menurunkan kandungan air bebas [16].

\section{Proksimat (kandungan abu)}

Hasil analisis kadar abu nugget kelinci New Zealand White sampel 1 mengandung abu sebesar 1,16\%, sampel 2 mengandung 0,58\%, dan sampel 3 mengandung 1,26\%. Rata-rata hasil analisis abu adalah 1,00\% (Tabel 5).

Tabel 5 Kandungan Abu dalam 100 g Nugget Kelinci New Zealand White

\begin{tabular}{ccccc}
\hline \multirow{2}{*}{ Parameter } & \multicolumn{3}{c}{ Sampel } & $\begin{array}{c}\text { Rata- } \\
\text { Rata }\end{array}$ \\
\cline { 2 - 5 } & 1 & 2 & 3 & 1,00 \\
\hline Abu $(\%)$ & 1,16 & 0,58 & 1,26 & 1,00 \\
\hline
\end{tabular}

Rata-rata kadar abu pada daging kelinci adalah sebesar $1 \%$ [17], sedangkan pada kadar abu bahan pengisi nugget, yaitu tepung maizena dan tepung terigu masing-masing sebesar $0.7 \%$ dan $0.5 \%$ [9]. Pada penelitian ini, kadar abu nugget kelinci tetap sebesar $1 \%$. Tidak adanya kerjasama antara kandungan mineral daging kelinci dengan bahan pengisi diduga menyebabkan tidak terdapatnya interaksi untuk mampu menurunkan atau meningkatkan persentase kadar abu dalam nuget kelinci. Dugaan ini diperkuat dengan hasil penelitian Arnyke, et al. (2014) [18], yang membuat nugget kelinci dengan bahan pengisi subtitusi berupa rumput laut, wheat bran, dan pollard tidak mempengaruhi nilai kadar abu nugget kelinci yaitu sebesar 1.59-1.86 \%. Kadar abu yang rendah ini menandakan sedikitnya penggunaan garam serta bahan pengawet yang digunakan dalam pengolahan [12] [19].

\section{Proksimat (kandungan karbohidrat)}

Hasil analisis kadar karbohidrat nugget kelinci New Zealand White sampel 1 mengandung 
karbohidrat sebesar 31,31\%, sampel 2 mengandung $32,47 \%$, dan sampel 3 mengandung 27,09\%. Rata-rata hasil analisis karbohidrat adalah 30,29\% (Tabel 6).

Tabel 6 Kandungan Karbohidat dalam 100 g Nugget Kelinci New Zealand White

\begin{tabular}{ccccc}
\hline \multirow{2}{*}{ Parameter } & \multicolumn{3}{c}{ Sampel } & $\begin{array}{c}\text { Rata- } \\
\text { Rata }\end{array}$ \\
\cline { 2 - 5 } & 1 & 2 & 3 & 30,29 \\
$\begin{array}{c}\text { Karbohidrat } \\
(\%)\end{array}$ & 31,31 & 32,47 & 27,09 & \\
\hline
\end{tabular}

Kadar karbohidrat dari nugget kelinci New Zealand White tergolong tinggi, yaotu $30.29 \%$ apabila dibandingkan dengan syarat mutu kandungan lemak nugget ayam menurut SNI Nugget Ayam 01-6683-2002 dengan syarat maksimal $25 \%$ berat basah [8]. Hal ini disebabkan karena bahan pengikat yang digunakan, yaitu tepung roti dan tepung maizena masing-masing memiliki kadar karbohidrat sebesar $72 \%$ dan $85 \%$ per 100 g, sehingga memberikan kontribusi nyata pada kadar karbohidrat nugget kelinci [10]. Dalam pengolahan nugget, kandungan pati pada karbohidrat akan mengikat air selama proses pengadonan dan selama pengukusan pati akan tergelatinisasi sehingga membentuk tekstur kekenyalan pada nugget [15].

\section{Analisis Komposisi Asam Lemak}

Hasil analisis komposisi asam lemak jenuh nugget kelinci pada pengulangan 1 sebesar $0,87 \%$, pengulangan 2 sebesar $1,38 \%$ dan pengulangan ke 3 sebesar $1,24 \%$. Rata-rata hasil analisis komposisi asam lemak jenuh adalah sebesar $1,16 \%$. Sedangkan hasil analisis komposisi asam lemak tidak jenuh nugget kelinci pada pengulangan 1 sebesar $1,32 \%$, pengulangan 2 sebesar $2,06 \%$, pengulangan 3 sebesar $1,84 \%$. Rata-rata hasil analisis komposisi asam lemak tidak jenuh adalah sebesar 1,74\% (Tabel 7)

Tabel 7 Kandungan asam lemak dalam 100 g Nugget Kelinci New Zealand White

\begin{tabular}{|c|c|c|c|c|}
\hline \multirow{2}{*}{ Parameter } & \multicolumn{3}{|c|}{ Sampel } & \multirow{2}{*}{$\begin{array}{l}\text { Rata- } \\
\text { Rata }\end{array}$} \\
\hline & 1 & 2 & 3 & \\
\hline $\begin{array}{c}\text { Lemak } \\
\text { Jenuh }(\%)\end{array}$ & 0,87 & 1,32 & 1,24 & 1,16 \\
\hline $\begin{array}{l}\text { Lemak } \\
\text { tidak jenuh }\end{array}$ & 1,32 & 2,06 & 1,84 & 1,74 \\
\hline
\end{tabular}

(\%)
Hasil penelitian menunjukkan bahwa kandungan asam lemak jenuh pada nugget kelinci memenuhi persyaratan klaim gizi BPOM (2016) yaitu rendah lemak jenuh di bawah $1,5 \mathrm{~g}$ per $100 \mathrm{~g}$ produk pangan. Komposisi asam lemak jenuh dan tidak jenuh pada daging kelinci masing-masing sebesar $1,660 \mathrm{~g} / 100 \mathrm{~g}$ dan $2,58 \mathrm{~g} / 100 \mathrm{~g}$ [20]. Komposisi asam lemak jenuh maupun tidak jenuh pada nugget kelinci memiliki kandungan yang lebih rendah dibandingkan dengan daging kelinci segar. Hal ini disebabkan adanya campuran bahan dasar pembuatan nugget yaitu tepung maizena, tepung terigu, dan susu bebas lemak sebagai bahan pengisi maupun pengikat. Telur memiliki kandungan asam lemak jenuh dan tidak jenuh yang lebih tinggi dibandingkan dengan daging kelinci, yaitu berkisar $3 \mathrm{~g} / 100 \mathrm{~g}$ [20]. Namun penambahan telur sebagai bahan pengikat tidak mempengaruhi peningkatan komposisi asam lemak jenuh dan tidak jenuh.

Asam lemak tidak jenuh memiliki kekentalan dan titik didih yang lebih kecil jika dibandingkan dengan asam lemak jenuh, karena pada asam lemak tak jenuh mempunyai ikatan rangkap yang besar sehingga asam lemak tidak jenuh kurang mampu bertahan pada suhu panas [21]. Pada penelitian ini proses pengukusan tidak menyebabkan komposisi asam lemak tidak jenuh menjadi lebih rendah dari asam lemak jenuh.

\section{Analisis Komposisi Asam Amino}

Hasil analisis kandungan asam amino nugget daging kelinci pada sampel 1 sebesar 12,49 g, sampel 2 sebesar 10,2 g, dan sampel 3 sebesar 12,19 g. Rata-rata hasil analisis kandungan asam amino nugget daging kelinci adalah 11,63 g per $100 \mathrm{~g}$ sampel (Tabel 8).

Tabel 8 Kandungan Asam Amino Nugget Daging Kelinci dalam g/100g

\begin{tabular}{lcccc}
\hline \multicolumn{1}{c}{ Jenis } & \multicolumn{3}{c}{ Sampel } & $\begin{array}{c}\text { Rata- } \\
\text { rata }\end{array}$ \\
\cline { 3 - 4 } \multicolumn{1}{c}{ Amino } & $\mathbf{1}$ & $\mathbf{2}$ & $\mathbf{3}$ & \\
\hline Asam & & & & \\
Amino & & & & \\
Esensial & 0,38 & 0,25 & 0,32 & 0,32 \\
Histidin & 0,91 & 0,61 & 0,74 & 0,75 \\
Arginin & 0,60 & 0,47 & 0,56 & 0,54 \\
Treonin & 0,65 & 0,53 & 0,62 & 0,60 \\
Valin & 0,58 & 0,48 & 0,57 & 0,54 \\
\hline
\end{tabular}




\begin{tabular}{lcccc}
\hline \multicolumn{1}{c}{$\begin{array}{c}\text { Jenis } \\
\text { Asam }\end{array}$} & \multicolumn{3}{c}{ Sampel } & $\begin{array}{c}\text { Rata- } \\
\text { rata }\end{array}$ \\
\cline { 3 - 4 } Amino & $\mathbf{1}$ & $\mathbf{2}$ & $\mathbf{3}$ & \\
\hline Isoleusin & & 0,83 & 0,98 & 0,94 \\
Leusin & 1,02 & 0,49 & 0,55 & 0,59 \\
Penilalanin & 0,72 & 0,89 & 1,17 & 1,01 \\
Lisin & 0,98 & & & \\
Asam & & & & \\
Amino & & & & \\
Non & 1,14 & 1,06 & 1,35 & 1,18 \\
Esensial & 2,24 & 2,21 & 2,48 & 2,31 \\
Asam & 0,65 & 0,51 & 0,57 & 0,58 \\
aspartat & 0,93 & 0,49 & 0,66 & 0,69 \\
Asam & 0,93 & 0,80 & 0,96 & 0,90 \\
glutamat & 0,76 & 0,58 & 0,66 & 0,67 \\
Serin & 12,4 & 10,2 & 12,19 & 11,63 \\
Glisin & 9 & & & \\
Alanin & & & & \\
Prolin & & & & \\
Total & & & & \\
\hline
\end{tabular}

Berdasarkan hasil analisis laboratorium didapat kandungan asam amino nugget daging kelinci terdiri atas 14 jenis asam amino yaitu 8 asam amino esensial dan 6 asam amino non esensial. Kandungan asam amino esensial tertinggi adalah lisin yaitu $1,01 \mathrm{~g} / 100 \mathrm{~g}$. Lisin berfungsi memperkuat sistem sirkulasi darah, bahan dasar antibodi, menurunkan kadar trigliserida darah, serta bersama prolin dan vitamin $\mathrm{C}$ akan membentuk jaringan kolagen [22]. Selain lisin, asam amino lain yang juga banyak terdapat pada nugget daging kelinci adalah leusin yaitu $0,94 \mathrm{~g} / 100 \mathrm{~g}$. Leusin bermanfaat untuk membantu menurunkan kadar gula darah, membantu penyembuhan tulang, jaringan otot dan kulit, serta memacu fungsi otak. Leusin juga berfungsi menjaga sistem imun [23] [24].

Asam glutamat dan asam aspartat merupakan asam amino non esensial yang memiliki kandungan tertinggi pada nugget daging kelinci yaitu 2,31 g/100g dan $1,18 \mathrm{~g} / 100 \mathrm{~g}$. Asam glutamat dan asam aspartat memiliki fungsi dalam hal menciptakan karakteristik aroma dan rasa pada makanan. Pada asam glutamat terdapat ion glutamat yang mampu merangsang beberapa saraf yang ada pada lidah manusia. Karakteristik tersebutlah yang banyak dimanfaatkan sebagai penyedap pada masakan [22].

Kandungan asam amino yang terdapat pada nugget daging kelinci telah memenuhi kebutuhan harian berdasarkan rekomendasi WHO, yaitu kebutuhan histidin sebesar $21.3 \%$, isoleusin $36 \%$, leusin $44.8 \%$, lisin $56.1 \%$, treonin $49 \%$, dan valin $40 \%$.

Daging kelinci segar terdapat kandungan asam amino tertinggi sebesar 96,04 g/100g [25], sedangkan berdasarkan hasil analisis nugget daging kelinci didapatkan kandungan asam amino yang lebih rendah yaitu $11,63 \mathrm{~g} / 100 \mathrm{~g}$. Penurunan kadar asam amino pada nugget daging kelinci diakibatkan karena pada nugget tidak menggunakan bahan campuran selain daging kelinci. Selain itu adanya faktor proses pemasakan yang menyebabkan menurunnya kadar asam amino pada nugget kelinci. Asam amino dapat rusak apabila mengalami proses pemanasan lebih $100^{\circ} \mathrm{C}$ [26].

\section{KESIMPULAN}

Nugget kelinci produk K3 mengandung protein $10,71 \%$, lemak total 3,34\%, kadar air 54,66 \%, kadar abu 1\%, dan karbohidrat 30,29\%. Nugget kelinci produk K3 juga mengandung asam lemak jenuh dan tidak jenuh sebesar 1,16 $\%$ dan $1,74 \%$. Selain itu, nugget produk K3 mengandung 8 jenis asam amino esensial dengan kandungan tertinggi 1,01\% lisin dan 6 asam amino non esensial dengan kandungan tertinggi $2,31 \%$ asam glutamat

\section{UCAPAN TERIMA KASIH}

Penulis Mengucapkan Terimakasih Kepada Tim Peneliti "Kelinci" Mahasiswa Jurusan Gizi, Fakultas Kedokteran, Universitas Brawijaya. Juga Untuk Komunitas Kelinci Kediri (K3) Atas Pembiayaan Dan Penyediaan Daging Kelinci Selama Penelitian Berlangsung. Tidak Lupa Penulis Mengucapkan Terimakasih Kepada Ibu Dr. Nurul Muslihah, Sp., M.Kes. Atas Bimbingannya Dalam Pembuatan Manuskrip Ini.

\section{DAFTAR ACUAN/PUSTAKA}

[1] Istiana, S. Zakariya, Zaenal A. Potensi Pengembangan Ternak Kelinci Mendukung Peningkatan Gizi Masyarakat di Kota Batu. Fakultas 
Pertanian Universitas Trunojoyoo: Madura. 2013

[2] Kementerian Pertanian. Outlook Komoditas Pertanian Sub SektorPeternakan Daging Sapi. Kementrian Pertanian: Jakarta. 2015

[3] Brahmantiyo, B. Raharjo, YC. Mansjoer, SS. Martojo,H. Performa Produksi Kelinci di Kabupaten Magelang, Jawa Tengah. Fakultas Peternakan IPB, Bogor. 2008

[4] Yanis M., Aminah S., Handayani Y., Ramdhan T. Karakteristik Produk Olahan Berbasis Daging Kelinci. Buletin Pertanian Perkotaan, 6 (2): 11-24. 2016

[5] Wijayanti, NW. Uji Biologis Pelet yang Mengandung Limbah Kubis Terfermentasi terhadap Profil Darah Kelinci New Zealand White Periode Pertumbuhan (Skripsi). Universitas Diponegoro: Semarang. 2017.

[6] Andarwulan, N., F. Kusnandar, dan D. Herawati.. Analisis Pangan. PT Dian Rakyat, Jakarta. 2011

[7] Slamet, A. Identifikasi Kandungan Gizi Makro dan Mikro serta Mutu Organaoleptik Nugget Berbahan Dasar Pisang Tanduk. Universitas Brawijaya: Malang. 2013.

[8] Badan Standardisasi Nasional. Nugget Ayam. SNI 01-6683-2002. Jakarta: Badan Standardisasi Nasional. 2002

[9] Afrisanti, D.W.. Kualitas Kimia dan Organoleptik Nugget Daging Kelinci dengan Penambahan Tepung Tempe (Skripsi). Fakultas Pertanian, Universitas Sebelas Maret, Surakarta. 2010

[10] Direktorat Gizi Depkes RI. Daftar Komposisi Bahan Makanan. Bharata Karya Aksara. Jakarta. 1995

[11] Sundari, Dian, Almasyhuri, dan Lamid, Astuti. Pengaruh Proses Pemasakan terhadap Komposisi Zat Gizi Bahan Pangan Sumber Protein. Depkes RI: Jakarta Pusat. 2015.

[12] Yuanita, I. dan Lisnowaty, S. Sifat Kimia dan Palatabilitas Nugget Ayam Menggunakan Jenis dan Konsentrasi Bahan Pengisi yang Berbeda. JIHT vol.3. No.1 Juni 2014

[13] Miratis, ST., Sulistiyati, TD., Suprayitno, E. Pengaruh Suhu Pengukusan terhadap Kandungan Gizi dan Organoleptik Abon Ikan Gabus (Ophiocphalus striatus), Vol. 1(1),33-45. 2013.
[14] Ockerman, H. W. Chemistry of Meat Tissue. $10^{\text {th }}$ Ed. Departemen of Animal Science. The Ohio State University. The Ohio Agriculture Research and Development Center, Ohio.1983.

[15] Wellyalina A., Aisman, F. Pengaruh Perbandingan Tetelan Merah Tuna dan Tepung Maizena Terhadap Mutu Nugget. JATP. Vol.2 No.1. 2013

[16] Kartikasari, L. R.. Pengaruh Ekstrak Hipofisis Sapid dan Level Protein Konsentrat Terhadap Kualitas Fisik Daging Kambing Kacang Jantan. Jurusan Peternakan. Fakultas Pertanian. Universitas Sebelas Maret. J. Sain Vet. 23 (2) 2005.

[17] Brahmantiyo, B., Setiawan, M. A., Yamin, M. Sifat Fisik dan Kimia Daging Kelinci Rex dan Lokal (Oryctolagus cuniculus).Jurnal Peternakan Indonesia, Vol. 16 (1) 2014.

[18] Arnyke, E.V., Rosyidi, D dan Radiati, L.E. Peningkatan potensi pangan fungsional naget daging kelinci dengan substitusi wheat bran, pollard dan rumput laut. Jurnal Ilmu-Ilmu Peternakan 24 (1): $56-71.2014$

[19] Yuliana, N., Pramono,Y.B., dan hintono, A. Kadar Lemak, Kekenyalan dan Cita Rasa Nugget Ayam yang Disubstitusi dengan Hati Ayam Broiler. Animal Agriculture Journal, 2(1), 301-308. 2013

[20] USDA. National Nutrient Database for Standard Reference Release 28. National Nutrient Database for Standard Reference Release 28.https://ndb.nal.usda.gov/ ndb/foods/show/5 279? fgcd $=$ Lamb\%2C + Veal\%2C+and+ Game+ Products \&manu $=\&$ lfacet $=\&$ format $=\&$ count $=\&$ mal8 Ferbuari $2018 x=35 \&$ offset $=\&$ sort $=\& q$ lookup $=r a$ bbit. JIHT vol.3. No.1 Juni 2014 (diakses 18 februari 2018)

[21] Winarno FG. Kimia Pangan dan Gizi edisi terbaru. Bogor. M-brio press.2008

[22] Purwaningsih S., Salamah E., Apriyana GP. Profil Protein dan Asam Amino Keong Ipong-Ipong (Fasciolaria salmo) pada Pengolahan yang Berbeda. Jurnal Gizi dan Pangan, Maret 2013, 8(1): 7782. 2013

[23] Liputo S.A., Berhimpon S., Fatimah F. Analisa nilai gizi serta kompinen asam amino dan asam lemak dari nugger ikan 
nike (Awaous melanocephalus) dengan penambahan tempe. Analisa Nilai Gizi Chem. Prog. Vol. 6 No.1. Mei 2013.

[24] Edison T. Amino acid: Esensial for our bodies. http://livewellnaturally.com. 2009. (Diakses 17 Februari 2018)

[25] Simonova,MP., Chrastinová, L., Mojto, J. Lauková, A. Szabóová,R. and Rafay, J. Quality of Rabbit Meat and Phyto-
Additives. Czech J. Food Sci. Vol. 28, No. 3: 161-167.2010

[26] Astiana, I. Perubahan Komposisi Asam Amino dan Mineral Belut Sawah (Monopterus albus) Akibat Proses Penggorengan. [Skripsi]. Fakultas Perikanan dan Ilmu Kelautan Institut Pertanian Bogor, Bogor. 2012. 